\title{
Subclinical hypothyroidism in pregnancy and outcomes
}

\author{
Anitha Sannaboraiah ${ }^{1 *}$, Rajani Upadhyaya ${ }^{2}$, Seeta Garag $^{3}$, Srinivasa Krishnappa ${ }^{4}$
}

\begin{abstract}
${ }^{1}$ Department of Obstetrics and Gynecology, Jindal Sanjeevani Hospital, Toranagallu, Bellary, Karnataka, India ${ }^{2}$ Department of Obstetrics and Gynecology, Sri Satya Sai Hospital, Puttaparthi, Andhra Pradesh, India ${ }^{3}$ Department of Obstetrics and Gynecology, Karnataka Institute of Medical Sciences, Hubli, Karnataka, India ${ }^{4}$ Department of Pediatrics, Navodaya Medical College, Raichur, Karnataka, India
\end{abstract}

Received: 18 February 2017

Accepted: 23 February 2017

\section{*Correspondence:}

Dr. Anitha Sannaboraiah,

E-mail: sanitha96@yahoo.in

Copyright: ( ) the author(s), publisher and licensee Medip Academy. This is an open-access article distributed under the terms of the Creative Commons Attribution Non-Commercial License, which permits unrestricted non-commercial use, distribution, and reproduction in any medium, provided the original work is properly cited.

\begin{abstract}
Background: Screening for subclinical hypothyroidism is essential in all pregnant women, especially in the Indian context, as Indian women have increased risk of developing iodine deficiency during pregnancy. Hence this study was undertaken to study the prevalence of subclinical hypothyroidism. Emphasis was put to know the need for universal screening and also the obstetric outcome in terms of perinatal morbidity and mortality and maternal morbidity were assessed.

Methods: It was a prospective analytical study. Sample size consisted of 200 pregnant women attending antenatal OPD. Thyroid profile (serum TSH, FT3 and FT4) was done during first visit and in subsequent trimester of each pregnant woman. The results were analyzed taking into consideration recent endocrine society guidelines. Patients with normal thyroid levels were taken as controls. Detailed history taken, physical examination and routine laboratory investigations were done. Patients with SCH were started on Levothyroxine and serial monitoring of TSH done until delivery. The patients were followed up to assess the mode of delivery, maternal and fetal outcome and any associated co-morbidities to serve the secondary objective of the study. Babies of SCH mothers were screened as well to rule out congenital hypothyroidism.

Results: Incidence of SCH was found to be $9.5 \%$ in the patients studied. Pregnant women with SCH had increased risks of developing anemia (31.5\%), preeclampsia (15\%), GDM (5\%) and prematurity (10\%), higher cesarean section rate $(36.8 \%)$. Neonates of women with SCH had higher incidence poor APGAR score (47.36\%), LBW (15\%), NICU admission (10\%), IUGR (5\%). Increased maternal age and more BMI were associated with higher incidence of subclinical hypothyroidism.

Conclusions: Prevalence of subclinical hypothyroidism among pregnant women is fairly high among Indians. Screening for subclinical hypothyroidism has to be included as a routine screening test and should be treated accordingly to improve maternal and fetal outcomes.
\end{abstract}

Keywords: Fetal outcome Pregnancy, Maternal outcome, Subclinical hypothyroidism

\section{INTRODUCTION}

Thyroid dysfunction is one of the most common endocrine disorders affecting women of reproductive age group including pregnancy. Over the past several years it has been proved that maternal thyroid disorder influence the outcome of mother and fetus, during and also after pregnancy. ${ }^{1}$

In pregnancy, overt hypothyroidism is seen in $0.2 \%$ cases and subclinical hypothyroidism $(\mathrm{SCH})$ is reported to have a prevalence of $1-2 \%$ of all pregnancies. ${ }^{1,2}$ The 
prevalence of hypothyroidism in pregnancy is around $2.5 \%$ according to the western literature. ${ }^{3}$ There are a few reports of prevalence of hypothyroidism during pregnancy from India with prevalence rates ranging from $4.8 \%$ to $11 \%$ and $\mathrm{SCH}$ is as high as $13.5 \%$ women. ${ }^{1,4,5}$ Despite of the known complications and adverse events due to thyroid abnormalities, there is ongoing debate regarding the need for universal screening for thyroid dysfunction during pregnancy. Current guidelines differ between aggressive cases finding approach versus testing only symptomatic women or those with a personal history of thyroid disease or other associated medical condition. 5,6-10 However, the effects of mild maternal thyroid deficiency with a normally functioning fetal thyroid gland are less clear. Somewhat related are previous reports that subclinical maternal hypothyroidism might be associated with poor pregnancy outcomes such as placental abruption, preterm birth, and low birth weight infants. ${ }^{11}$ Since the earlier estimates of prevalence for $\mathrm{SCH}$ are based on region, assay, and trimesterspecific TSH cut-offs, there is large variation in prevalence of $\mathrm{SCH}$ and data regarding the $\mathrm{SCH}$ in Indian pregnant women is scant. Hence this study was undertaken to estimate the prevalence of $\mathrm{SCH}$ and find out the pregnancy outcome in women with $\mathrm{SCH}$.

\section{METHODS}

This study was a hospital based time bound prospective analytical study. The study included total of 200 antenatal cases, which was further divided into study and control groups based on the inclusion and exclusion criteria as mentioned below.

\section{Inclusion criteria}

- $\mathrm{TSH}>2.5 \mathrm{mIU} / \mathrm{L}$ in $1^{\text {st }}$ trimester.

- $\mathrm{TSH}>3 \mathrm{mIU} / \mathrm{L}$ in $2^{\text {nd }}$ trimester.

- $\mathrm{TSH}>3.5 \mathrm{mIU} / \mathrm{L}$ in $3^{\text {rd }}$ trimester.

- Normal FT4.

- Normal FT3.

\section{Exclusion criteria}

- Pre-existing thyroid disorders.

- Patients presenting with symptoms of overt hypothyroidism.

Patient's consent was taken for the study. Thyroid profile (serum TSH, FT3 and FT4) was done during their first visit and in subsequent trimester. The results were analysed taking into consideration recent endocrine society guidelines. Patients with normal thyroid levels were taken as controls. General demographic details like age, occupation, income, significant past history, menstrual history and personal habits were taken. Other general physical examination and obstetric examination were done.
Obstetric ultrasound was done to rule out other anomalies. Routine laboratory investigations like $\mathrm{Hb}$, GCT, urine routine and tests were done to rule out HIV, HBV and Syphilis. The patients were followed up to assess the mode of delivery, maternal and fetal outcome and any associated co-morbidities to serve the secondary objective of the study.

As there are no standard cut off criteria for TSH to label it as subclinical hypothyroidism, European Thyroid Association Guidelines 2014 was taken into consideration in our study. SCH was diagnosed if TSH $>2.5 \mathrm{mIU} / \mathrm{L}$ in $1^{\text {st }}$ trimester, $>3 \mathrm{mIU} / \mathrm{L}$ and $>3.5 \mathrm{mIU} / \mathrm{L}$ in $2^{\text {nd }}$ trimester and $3^{\text {rd }}$ trimester respectively provided normal free $\mathrm{T} 3$ and $\mathrm{T} 4$. Patients with SCH were treated accordingly and babies born to $\mathrm{SCH}$ mothers were also screened for congenital hypothyroidism.

\section{Maternal outcome}

- Preeclampsia.

- Anemia.

- Preterm labor.

- Mode of delivery.

\section{Fetal outcome}

- $\quad$ Low birth weight (LBW).

- Intra uterine growth retardation (IUGR).

- Poor APGAR score.

- NICU admission.

\section{Statistical analysis}

The results for continuous variables were expressed as mean +/- SD and proportions as percentages. The difference between the values and outcome were assessed by the Chi-square, Fisher exact test and student test when appropriate. Odds ratio/Risk ratio and $90 \%$ confidence interval were the other study parameters which were used when appropriate for statistical analysis of this study. For all the tests a P value of 0.05 or less was considered for statistical significance.

\section{RESULTS}

Out of 200 pregnant women included in present study 19 women had SCH with an incidence of $9.5 \%$ as shown in Table 1 .

Table 1: Incidence of subclinical hypothyroidism.

\begin{tabular}{|lll|}
\hline Subclinical & \multicolumn{2}{l|}{ Distribution $(\mathrm{n}=200)$} \\
\hline hypothyroidism & Number & Percentage \\
\hline Present & 19 & 9.50 \\
\hline Absent & 181 & 90.50 \\
\hline Total & $\mathbf{2 0 0}$ & $\mathbf{1 0 0 . 0 0}$ \\
\hline
\end{tabular}


Incidence of $\mathrm{SCH}$ in patients aged $\leq 20$ years was $5.26 \%$. Incidence of $\mathrm{SCH}$ in patients aged 21-25 years was $26.31 \%$. Incidence of $\mathrm{SCH}$ in patients aged $26-30$ years was $36.84 \%$. Incidence of $\mathrm{SCH}$ in patients aged 31-35 years was $31.57 \%$. SCH was more common in elderly gravidas. There was a strong association between $\mathrm{SCH}$ and elderly gravidas $(\mathrm{p}=0.018)$ (Table 2). Anemia was more in $\mathrm{SCH}$ patients (Hb less than $11 \mathrm{gm} \%$ ) than normal pregnancy with incidence of about $31.57 \%$ (Table 3 ).

Table 2: Distribution of study population according to the maternal age and its association with SCH.

\begin{tabular}{|c|c|c|c|c|c|c|}
\hline \multirow{3}{*}{$\begin{array}{l}\text { Maternal age } \\
\text { (Years) }\end{array}$} & \multicolumn{4}{|c|}{ Sub-clinical hypothyroidism } & \multirow{2}{*}{\multicolumn{2}{|c|}{ Total }} \\
\hline & \multicolumn{2}{|c|}{ Absent } & \multicolumn{2}{|l|}{ Present } & & \\
\hline & $\mathrm{N}$ & Percent & Number & Percent & Number & Percent \\
\hline 20 or less & 21 & 95.45 & 1 & 4.55 & 22 & 11.00 \\
\hline 21 to 25 & 48 & 90.57 & 5 & 9.43 & 53 & 26.50 \\
\hline 26 to 30 & 99 & 93.40 & 7 & 6.60 & 106 & 53.00 \\
\hline 31 to 35 & 13 & 68.42 & 6 & 31.58 & 19 & 9.50 \\
\hline Total & 181 & 90.50 & 19 & 9.50 & 200 & 100.00 \\
\hline
\end{tabular}

$\mathrm{P}=0.018$

Table 3: Distribution of study population according to the haemoglobin levels and its association with SCH.

\begin{tabular}{|lllllll||}
\hline $\begin{array}{l}\text { Haemoglobin levels } \\
(\text { gm\%) }\end{array}$ & \multicolumn{2}{l}{$\begin{array}{l}\text { Sub-clinical hypothyroidism } \\
\text { Absent }\end{array}$} & \multicolumn{2}{l}{ Present } & & Total \\
& Number & Percentage & Number & Percentage & Number & Percentage \\
\hline$<11$ & 90 & 93.75 & 6 & 6.25 & 96 & 44.50 \\
\hline 11 or more & 91 & 87.5 & 13 & 12.5 & 104 & 55.50 \\
\hline Total & $\mathbf{1 8 1}$ & $\mathbf{9 0 . 5 0}$ & $\mathbf{1 9}$ & $\mathbf{9 . 5 0}$ & $\mathbf{2 0 0}$ & $\mathbf{1 0 0 . 0 0}$ \\
\hline
\end{tabular}

$\mathrm{p}=0.234$.

Table 4: Distribution of study population according to the preeclampsia and its association with SCH.

\begin{tabular}{|c|c|c|c|c|c|c|}
\hline \multirow{3}{*}{ Preeclampsia } & \multicolumn{4}{|c|}{ Sub-clinical hypothyroidism } & \multirow{2}{*}{\multicolumn{2}{|c|}{ Total }} \\
\hline & \multicolumn{2}{|c|}{ Absent } & \multicolumn{2}{|l|}{ Present } & & \\
\hline & Number & Percentage & Number & Percentage & Number & Percentage \\
\hline Yes & 21 & 87.50 & 3 & 12.50 & 24 & 12.00 \\
\hline No & 160 & 90.91 & 16 & 9.09 & 176 & 88.00 \\
\hline Total & 181 & 90.50 & 19 & 9.50 & 200 & 100.00 \\
\hline
\end{tabular}

$\mathrm{p}=0.405$.

Table 5: Distribution of study population according to the mode of delivery and its association with SCH.

\begin{tabular}{|c|c|c|c|c|c|c|}
\hline \multirow{3}{*}{$\begin{array}{l}\text { Mode of } \\
\text { delivery }\end{array}$} & \multicolumn{4}{|c|}{ Sub-clinical hypothyroidism } & \multirow{2}{*}{\multicolumn{2}{|c|}{ Total }} \\
\hline & Absent & & Present & & & \\
\hline & Number & Percentage & Number & Percentage & Number & Percentage \\
\hline FTND & 130 & 91.55 & 12 & 8.45 & 142 & 71.00 \\
\hline LSCS & 51 & 87.93 & 7 & 12.07 & 58 & 29.00 \\
\hline Total & 181 & 90.50 & 19 & 9.50 & 200 & 100.00 \\
\hline
\end{tabular}

Preeclampsia was more in SCH patients than normal pregnancy with incidence of about $15.78 \%$ (Table 4). LSCS rate was more in $\mathrm{SCH}$ patients than normal pregnancy with incidence of about $36.84 \%$ (Table 5). Prematurity was more in $\mathrm{SCH}$ patients than normal pregnancy with incidence of about $10.52 \%$ (Table 6). IUGR was more in SCH patients than normal pregnancy with incidence of about $5.26 \%$ (Table 7). LBW was more in $\mathrm{SCH}$ patients than normal pregnancy with incidence of about $15.78 \%$. There was a strong association between $\mathrm{SCH}$ and LBW (p=0.001) (Table 8).

Poor APGAR score was more in $\mathrm{SCH}$ patients than normal pregnancy with incidence of about $47.36 \%$ (Table 
9). NICU admission is seen more in babies born to SCH mother than normal pregnancy with incidence of about
$10.52 \%$ (Table 10). Causes for NICU admission were fetal distress, low APGAR score, prematurity and IUGR.

Table 6: Distribution of study population according to the prematurity and its association with SCH.

\begin{tabular}{|lllllll|}
\hline \multirow{2}{*}{ Prematurity } & \multicolumn{2}{l}{ Sub-clinical hypothyroidism } & & & Total \\
& Absent & & Present & & Number & Percentage \\
\hline Number & Percentage & Number & Percentage & 18 & 9.00 \\
\hline Yes & 16 & 88.89 & 2 & 11.11 & 18 & 91.00 \\
\hline Total & 165 & 90.66 & 17 & 9.34 & 182 & $\mathbf{1 0 0 . 0 0}$ \\
\hline
\end{tabular}

$\mathrm{p}=0.53$.

Table 7: Distribution of study population according to the IUGR and its association with SCH.

\begin{tabular}{|c|c|c|c|c|c|c|}
\hline \multirow{3}{*}{ IUGR } & \multicolumn{4}{|c|}{ Sub-clinical hypothyroidism } & \multirow{2}{*}{\multicolumn{2}{|c|}{ Total }} \\
\hline & \multicolumn{2}{|c|}{ Absent } & \multicolumn{2}{|l|}{ Present } & & \\
\hline & Number & Percentage & Number & Percentage & Number & Percentage \\
\hline Yes & 21 & 95.45 & 1 & 4.55 & 22 & 11.00 \\
\hline No & 160 & 89.89 & 18 & 10.11 & 178 & 89.00 \\
\hline Total & 181 & 90.50 & 19 & 9.50 & 200 & 100.00 \\
\hline
\end{tabular}

$\mathrm{P}=0.352$.

Table 8: Distribution of study population according to the birth weight and its association with SCH.

\begin{tabular}{|c|c|c|c|c|c|c|}
\hline \multirow{3}{*}{ Birth weight (Kgs) } & \multicolumn{4}{|c|}{ Sub-clinical hypothyroidism } & \multirow{2}{*}{\multicolumn{2}{|c|}{ Total }} \\
\hline & Absent & & Present & & & \\
\hline & Number & Percentage & Number & Percentage & Number & Percentage \\
\hline 2.000 to 2.499 & 13 & 81.25 & 3 & 18.75 & 16 & 8.00 \\
\hline 2.500 to 3.499 & 158 & 91.32 & 15 & 8.68 & 173 & 90.00 \\
\hline 3.500 or more & 10 & 90.90 & 1 & 9.09 & 11 & 2.00 \\
\hline Total & 181 & 90.50 & 19 & 9.50 & 200 & 100.00 \\
\hline
\end{tabular}

$\mathrm{p}=0.001$.

Table 9: Distribution of study population according to the APGAR score at 1 minute and its association with SCH.

\begin{tabular}{|c|c|c|c|c|c|c|}
\hline \multirow{3}{*}{$\begin{array}{l}\text { APGAR score at } \\
1 \text { minute }\end{array}$} & \multicolumn{4}{|c|}{ Sub-clinical hypothyroidism } & \multirow{2}{*}{\multicolumn{2}{|c|}{ Total }} \\
\hline & Absent & & Present & & & \\
\hline & Number & Percentage & Number & Percentage & Number & Percentage \\
\hline$<7$ & 25 & 73.52 & 9 & 26.47 & 34 & 17.00 \\
\hline 7 or more & 156 & 93.97 & 10 & 6.02 & 166 & 83.00 \\
\hline Total & 181 & 90.50 & 19 & 9.50 & 200 & 100.00 \\
\hline
\end{tabular}
$\mathrm{p}=0.396$.

Table 10: Distribution of study population according to the NICU admission and its association with SCH.

\begin{tabular}{|lllllll|}
\multirow{2}{*}{ NICU admission } & \multicolumn{2}{l}{ Sub-clinical hypothyroidism } & & & Total \\
& Absent & \multicolumn{3}{c|}{ Present } \\
& Number & Percentage & Number & Percentage & Number & Percentage \\
\hline Yes & 20 & 90.90 & 2 & 9.09 & 22 & 11.00 \\
\hline No & 161 & 90.44 & 17 & 9.55 & 178 & 89.00 \\
\hline Total & $\mathbf{1 8 1}$ & $\mathbf{9 0 . 5 0}$ & $\mathbf{1 9}$ & $\mathbf{9 . 5 0}$ & $\mathbf{2 0 0}$ & $\mathbf{1 0 0 . 0 0}$ \\
\hline
\end{tabular}




\section{DISCUSSION}

Subclinical hypothyroidism ( $\mathrm{SCH})$ is the commonest form of hypothyroidism in pregnancy; it comprises of high or normal thyroid-stimulating hormone (TSH) with thyroxin (T4) levels in normal or low normal range.

There has been a debate for a long time about the upper limit of normal TSH during pregnancy. Recent guidelines by American Thyroid Association (ATA) and the National Association of Clinical Biochemists have reduced this to $2.5 \mathrm{~m} \mathrm{IU} / \mathrm{L}$ in $1^{\text {st }}$ trimester and $3.0 \mathrm{~m}$ IU/L in 2nd / 3rd trimesters. This was done because it was seen that in more than $95 \%$ of rigorously screened euthyroid volunteers, the normal range was from 0.4 to $2.5 \mathrm{~m} \mathrm{IU} / \mathrm{L}$. This of course increases the disease frequency of hypothyroidism in pregnancy up to 5 -fold. ${ }^{12}$

Dhanwal et al in his study showed an $\mathrm{SCH}$ prevalence of $4.3 \%$ among the pregnant women in north India. ${ }^{13}$ Abalovich et al in the year 2007 estimated overt hypothyroidism to occur in $0.3-0.5 \%$ of pregnancies. ${ }^{14}$ Subclinical hypothyroidism appears to occur in $2-3 \%$, and hyperthyroidism in $0.1-0.4 \%$. Gayathri et al in the year 2007 analysed the prevalence of SCH among 495 pregnant women attending Government hospitals in South India and showed that prevalence was $2.8 \%$ in her study. ${ }^{15}$ Forough et al in the year 2012 conducted a study on 600 pregnant women in Iran and showed $11.3 \%$ prevalence of SCH. ${ }^{16}$ Present study shows the prevalence of $9.5 \%$ of subclinical hypothyroidism. Present study is comparable with Forough studies.

Lahoti et al reported complication like preeclampsia as high as $15 \%$ compared to normal population $(7.9 \%)$ in their study. ${ }^{17}$ In present study we found similar incidence of $15 \%$ as compared to normal $(11.6 \%)$. The association between preeclampsia and subclinical hypothyroidism ( $\mathrm{p}$ value $>0.05$ ) in present study was not significant, it may be attributed to less number of study subjects in present study.

Akter et al conducted a study on 50 pregnant women among them 29 were $\mathrm{SCH}$ and 21 were $\mathrm{OH}$, the commonest problem in both groups was anemia. ${ }^{18} \mathrm{He}$ concluded that $17.2 \%$ of patients with subclinical hypothyroidism were anaemic and $42.9 \%$ patients with overt hypothyroidism suffered anemia. Whereas, in our study 6 out of $19 \mathrm{SCH}$ patients were found having anemia $(31.5 \%)$.

In the present study out of 19 patients with adequate thyroxine replacement, two had premature labour $(10.5 \%)$. Green et al in year 2005 in their prospective study of women with untreated subclinical hypothyroidism found that compared to euthyroid women they were three times more likely to develop placental abruption and 1.8 times more likely to experience preterm labour. ${ }^{19}$ Casey et al in the year 2005 using a prospective study design of 16,000 young pregnant women (mean age 25.5 years), showed that subclinical hypothyroidism in the second trimester is associated with a significantly increased risk of placental abruption, preterm birth, and respiratory distress. ${ }^{20}$ Abalovich et al in year 2002 observed adequate thyroxine replacement for women with mild or overt hypothyroidism in early pregnancy results in term delivery in $90 \%$ but failure to achieve normal TSH during pregnancy has been associated with term delivery in only $20 \%{ }^{1}$

In this study 7 out of 19 patients underwent cesarean section $(36.8 \%)$ in comparable with study by Sreelakshmi et al which showed cesarean section rate was 28 out of $101 \mathrm{SCH}$ patients (27.7\%). ${ }^{21}$ Rooplekha et al showed that women with subclinical hypothyroid, $77.5 \%$ delivered vaginally and $22.5 \%$ by caesarian section. ${ }^{22}$ This analysis showed that requirement of caesarian section was statistically more in hypothyroid cases with $p$ value $=0.042$ and this difference were statistically significant. In present study among 7 patients four were elective, two patients had been induced later underwent emergency section for fetal distress, Meenakshi et al in her study defined that cesarean section rate for fetal distress was significantly higher among pregnant with subclinical hypothyroidism $(\mathrm{p}=0.04)$. Present study is comparable with above studies. ${ }^{23}$

In present study 6 out of 19 patients were elderly gravidas (age 31-35 years). There was a positive correlation between subclinical hypothyroidism and higher maternal age $(\mathrm{p}=0.018)$. The study by Kalpesh et al had similar results i.e., increased maternal age was associated with higher incidence of thyroid dysfunction. ${ }^{24}$ The reason for increased prevalence of hypothyroidism in the older age group is due to current trend of older women becoming pregnant.

In present study out of $19 \mathrm{SCH}$ patients 5 patients had BMI more than $26 \mathrm{~kg} / \mathrm{m}^{2}(\mathrm{p}=0.005)$. Knudsen et al in the year 2005 found a positive association between BMI and serum TSH $(P<0.001) .{ }^{25}$ They proved that elevated serum TSH levels are associated with an increase in the occurrence of obesity. Similarly, present study also had a strong association between SCH and BMI in present study, the reason for this may be same as quoted in the above study.

Incidence of LBW in our study is found to be $15 \%, 3$ out of 19 babies had birth weight <2.5kgs. Frances et al proved that women with overt hypothyroidism were more likely to deliver LBW $(<2500 \mathrm{~g})$ babies than those in the general population $(22 \%$ versus $6.8 \%$, respectively; $\mathrm{p}<$ $0.02){ }^{26}$ The rate of LBW babies born to women with subclinical hypothyroidism was 9\%. In Akter et al low birth weight babies were also common in patients with overt hypothyroidism $(80 \%)$ than in patients with subclinical hypothyroidism $(27.6 \%) .{ }^{18}$

In present study 9 out of 19 babies had APGAR score less than 7 (47.36\%). In Akter et al $62.1 \%$ of babies from 
mothers having subclinical hypothyroidism had APGAR score of 7 whereas $73.3 \%$ of babies from mothers having overt hypothyroidism had APGAR score of 6 in the first minute. ${ }^{18}$ Forough et al showed low APGAR score at first minute $(\mathrm{P}=0.022)$, it increased the risk of low APGAR score by 2.15 times. $^{16}$

In present study two babies needed ICU care after delivery (10\%), whereas in a study by Akter et al $13.8 \%$ of babies in group I (SCH) and $20.0 \%$ of babies in group II $(\mathrm{OH})$ were sent to NICU. ${ }^{18}$ The study by Rooplekha et al showed that $27.5 \%$ of subclinical hypothyroid group and $80 \%$ of overt hypothyroid group babies were admitted in NICU. ${ }^{22}$

In the current study one baby had IUGR $(5 \%)$ where as in a study by Lahoti et al IUGR was $2.7 \% .{ }^{17}$ Forough et al in his study showed subclinical hypothyroidism had a significant association with IUGR $(\mathrm{P}=0.028)$, it increased the risk of IUGR by 2.18 times. $^{16}$

\section{Limitations of the study}

- Anti TPO antibody testing was not done because this test was not available in our institute.

- This study would have been more effective qualitatively and quantitatively if the estimation of serum iodine was included along with TSH and the free hormonal estimation. ${ }^{27}$

- This study would have given more accurate results if the same subjects were taken as controls before pregnancy and were followed during pregnancy, which could not be done in this study because of time factor.

\section{CONCLUSION}

In this study the maternal and fetal adverse outcomes were not higher as compared to other studies. Other studies have shown that adverse events do occur in pregnant women with subclinical hypothyroidism, but not in women with hypothyroidism on replacement therapy with Levothyroxine. Treatment improves outcomes and reduces the rate of complications. These findings provide evidence for the importance of identification and treatment of subclinical hypothyroidism in pregnancy.

Funding: No funding sources

Conflict of interest: None declared

Ethical approval: The study was approved by the Institutional Ethics Committee

\section{REFERENCES}

1. Abalovich M, Gutierrex S, Alcaraz G. Overt and subclinical hypothyroidism complicating pregnancy. Thyroid. 2002;12:63-8.

2. Casey BM, Leveno KJ. Thyroid disease in pregnancy. Obstet Gynecol. 2006;108:1283-92.
3. Subclinical Hypothyroidism in Pregnancy. Washington DC: ACOG Practice Guidelines; 2007.

4. Lazarus JH. Screening for thyroid dysfunction in pregnancy: is it worthwhile? J Thyroid Res. 2011;3:97-112.

5. Garber JR, Cobin RH, Gharib H, Hennessey JV, Klein I, Mechanick JI, et al. Clinical practice guidelines for hypothyroidism in adults: cosponsored by American Association of Clinical Endocrinologists and the American Thyroid Association. Endocr Pract. 2012;18(6):988-1028.

6. De Groot L, Abalovich M, Alexander EK, Amino N, Barbour L, Cobin RH, et al. Management of thyroid dysfunction during pregnancy and postpartum: an Endocrine Society clinical practice guideline. J Clin Endocrinol Metab. 2012;97(8):2543-65.

7. Stagnaro-Green A, Abalovich M, Alexander E, Azizi F, Mestman J, Negro R, et al. Guidelines of the American Thyroid Association for the diagnosis and management of thyroid disease during pregnancy and postpartum. Thyroid. 2011;21(10):1081-125.

8. Reid SM, Middleton P, Cossich MC, Crowther CA. Interventions for clinical and subclinical hypothyroidism in pregnancy. Cochrane Database of Systematic Reviews. 2010;7:CD007752.

9. Gyamfi-Bannerman C. Society for Maternal-Fetal Medicine (SMFM), Screening for thyroid disease during pregnancy. Contemporary Obstet Gynecol. 2012;57(8):112-5.

10. Committee on Patient Safety and Quality Improvement and Committee on Professional Liability. ACOG Committee Opinion No. 381: subclinical hypothyroidism in pregnancy. Obstet Gynecol. 2007;110(4):959-60.

11. Casey BM, Dashe JS, Wells CE. Subclinical hyperthyroidism and pregnancy outcomes. Obstet Gynecol. 2006;107:337-41.

12. Baloch Z, Carayon P, Conte DB, Demers LM, Feldt RU, Henry JF et al. Laboratory Medicine Practice Guidelines. Laboratory support for the diagnosis and monitoring of thyroid disease. Thyroid. 2003;13:12326.

13. Dhanwal DK, Prasad S, Agarwal AK, Dixit V, Banerjee AK. High prevalence of subclinical hypothyroidism during first trimester of pregnancy in North India. Indian $\mathrm{J}$ Endocrinol Metab. 2013;17(2):281-4.

14. Abalovich M, Amino N, Barbour LA, Cobin RH, De Groot LJ, Glinoer D. Management of thyroid dysfunction during pregnancy and postpartum: an Endocrine Society Clinical Practice Guideline. J Clin Endocrinol Metab. 2007;92(8):S1-47.

15. Gayathri R, Lavanya S, Raghavan K. Subclinical hypothyroidism and autoimmune thyroiditis in pregnancy- a study in South Indian subjects. J Assoc Physicians India. 2009;57:691-3.

16. Saki F, Dabbaghmanesh MH, Ghaemi SZ, Forouhari S, Omrani GR, Bakhshayeshkaram M. Thyroid function in pregnancy and its influences on maternal 
and fetal outcomes. Int $\mathrm{J}$ Endocrinol Metab. 2014;12(4):19378.

17. Lahoti SK, Toppo L. Subclinical hypothyroidism and pregnancy outcomes. Ann Int Med Den Res. 2015;1(3):324-6.

18. Akter SN, Tarannum R, Kabir MS. Pregnancy in overt and subclinical hypothyroidism and its fetomaternal outcome. J Med Today. 2013;25:02.

19. Green AS, Chen X, Bogden JD, Davies TF, Scholl TO. The thyroid and pregnancy: a novel risk factor for very preterm delivery. Thyroid 2005;15:351-7.

20. Casey BM, Dashe JS, Wells CE, McIntire DD, Byrd W, Leveno KJ, et al. Subclinical hypothyroidism and pregnancy outcomes. Obstet Gynecol. 2005;105:23945 .

21. Sreelakshmi U, Divya J Tekani. Evaluation of effects of subclinical hypothyroidism on pregnancy and its outcome. Int J Sci Res. 2013;4(9):1524-7.

22. Rooplekha C, Sahu B, Khan S. Prevalence of hypothroidism among pregnant women in Mahakaushal area and its impact on maternal and fetal outcome. Int J Med Applied Sci. 2015;4(1):1407.

23. Meenakshi TS, Vinita D, Suneeta M, Anjoo A, Monashis S. Overt and subclinical thyroid dysfunction among Indian pregnant women and its effect on maternal and fetal outcome. Arch Gynecol Obstet. 2010;281(2):215-20.

24. Kalpesh K, Alpesh P, Harshid L. High prevalence of thyroid dysfunction among pregnant women in Ahmedabad City, Gujarat, India. Int J Adv Res. 2015;3(8):676-82.

25. Knudsen N, Laurberg P, Lone BR, Bülow I, Perrild $\mathrm{H}$, Ovesen L, et al. Small differences in thyroid function may be important for body mass index and the occurrence of obesity in the population. J Clin Endocrinol Metab. 2013;90(7):4019-24.

26. Frances A, Cindy LF. Clinical Controversies in Screening Women for Thyroid Disorders During Pregnancy. J Midwifery Womens Health. 2006;51(3):152-8.

27. Kriplani A, Buckshee K, Bhargava VL, Takker D, Ammini AC. Maternal and perinatal outcome in thyrotoxicosis complicating. Eur J Obstet Gynecol Reproductive Biol. 1994;54(3):159-63.

Cite this article as: Sannaboraiah A, Upadhyaya R, Garag S, Krishnappa S. Subclinical hypothyroidism in pregnancy and outcomes. Int J Reprod Contracept Obstet Gynecol 2017;6:1215-21. 